профессиональной самоиндетификации у студентов педвуза / Л. Н. Захарова // Вопросы психологии. -1991. - № 2. - С. 16. 3. Кузьмина Н. В. Профессионализм личности преподавателя и мастера производственного обучения / Н. В. Кузьмина. М. : Просвещение, 1990. - С. 312. 4. Митина Л. М. Психология профессионального развития / Л. М. Митина. - М. : Флинта, 1998. - С. 38-41. 5. Науменко Е. А. Психологическая структура и формирование профессионально-педагогической направленности личности: автореф. дис. ... канд. псих. наук: спец. 19.00.01/ Е. А. Науменко. - М., 1987. - 22 с. 6. Пилипенко Н. В. Вплив кризи професійного становлення на саморозвиток особистості / Н. М. Пилипенко // Педагогіка i психологія. - 2005. - № 2. - С. 117-118. 7. Рубинштейн С. Л. Проблемы общей психологи / С. Л. Рубинштейн. - M. : Просвещение, 1976. - С. 415. 8. Фастовец П. В. Формирование профессионально-педагогической направленности личности учителя : автореф. дис. ... канд. псих. наук : спец. 19.00.01 / Фастовец П. В. - М. , 1998. - 20 с.

Наталя Мозгальова

\title{
КОНЦЕПТУАЛЬНІ ПІДХОДИ ДО ОНОВЛЕННЯ ЗМІСТУ ІНСТРУМЕНТАЛЬНО-ВИКОНАВСЬКОЇ ПІДГОТОВКИ ВЧИТЕЛІВ МУЗИКИ
}

Мозгальова Н. Г. Концептуальні підходи до оновлення змісту інструментальновиконавської підготовки вчителів музики.

У статті запропоновано концептуальні засади інструментально-виконавської підготовки вчителів музики. Теоретично обгрунтовано сутність і специфіку таксономічного підходу в галузі інструментального виконавства. Визначено мету, завдання, принципи навчання в інструментальному класі. Наголошено, що підвищення якості інструментально-виконавської підготовки можливе, якщо перетворити процес навчання гри на музичних інструментах на організаційнометодичну систему, розроблення якої необхідно здійснювати 3 урахуванням визначених ідей.

Ключеві слова: концептуальні засади, інструментально-виконавська підготовка, вчитель музики, цілі, таксономічний підхід.

Мозгалева Н. Г. Концептуальные подходы к обновлению содержания инструментально-исполнительской подготовки учителей музыки.

В статье обосновываются концептуальные основы инструментальноисполнительской подготовки учителей музыки. Теоретически обосновано сущность и специфика таксономического подхода в области инструментального исполнительства. Определены цели, задачи, принципы обучения в фортепианном классе. Отмечено, что повышение качества инструментально-исполнительской подготовки возможно, если представить процесс обучения игры на музыкальных инструментах как организационно-методическую систему, моделирование которой необходимо осуществлять с учетом определенных идей.

Ключевые слова: концептуальные основы, инструментально-исполнительское подготовка, учитель музыки, цели, таксономический подход.

Mozgaleva N. G. Conceptual approaches to update the content of instrumental music teachers pidgotovki executive. 
The paper proposes a conceptual basis performing instrumental music teacher training. In theory, the essence and specificity of the taxonomic approach in instrumental performance. Defined goals, objectives, principles, training in instrumental teachers. Emphasized that improving the quality of instrumental performance training possible if the transform process of learning to play a musical instrument for organizational and methodical system development which must take into account the identified ideas.

Key words: conceptual foundations, instrumental performance in training, music teacher, goals, taxonomic approach.

Після здобуття незалежності України урядом закцентовано увагу на проблемі забезпечення якості вищої освіти. Все це зумовлює необхідність дослідження комплексу питань, пов'язаних з удосконаленням змістово-організаційних заходів, теоретико-методичного супроводу дисциплін, які забезпечують процес інструментально-виконавської підготовки вчителів музики.

Питання фахової підготовки вчителів музики знайшли широке відображення у працях науковців. Так, досліджено шляхи забезпечення цілісної професійної підготовки майбутнього педагога-музиканта (Е. Абдуллін, Г. Падалка, О. Ростовський, О. Рудницька, О. Щолокова та ін.), розроблено професіограму вчителя музики (Л. Арчажникова). Досліджуючи процес інструментальновиконавської підготовки вчителів музики, науковці зосереджують свою увагу переважно на окремих аспектах процесу навчання гри на музичних інструментах, розглядаючи окреслене питання 3 позицій історико-стильового (О. Щербініна) та системного (Г. Ципін) підходів, формування виконавської культури (Н. Згурська), готовності до виконавської діяльності (Л. Гусейнова), організації навчальної взаємодії в інструментальному класі (В. Ревенчук) та ін. За безумовної важливості цих досліджень спостерігається відсутність цілісності й концептуальності в дослідженні проблеми інструментально-виконавської підготовки вчителів музики.

Mета статті полягає в обгрунтуванні концептуальних підходів до оновлення змісту інструментально-виконавської підготовки майбутніх учителів музики.

Формулювання концептуальних засад дослідження теорії та методики інструментально-виконавської підготовки майбутніх учителів музики грунтується на нормативно-правових документах (Конституції України, Національній доктрині розвитку освіти (2002), Законі України «Про вищу освіту» (2002), Державній національній програмі «Освіта» (Україна XXI століття)), які окреслюють основні принципові положення із забезпечення якості освіти на сучасному етапі.

Оскільки пріоритетним напрямом нашої роботи визначено підвищення якості інструментально-виконавської підготовки, провідним концептуальним орієнтиром дослідження обрано таксономічний підхід. Це зумовлено тим, що якість інструментально-виконавської підготовки вчителів музики перебуває в прямій залежності від взаємоузгодженості соціальних (зафіксованих у нормативних документах), особистісних (зорієнтованих на потреби та очікування студентів) i педагогічних (визначених викладачами стосовно окремих дисциплін і навчальних занять) цілей. Обгрунтовуючи педагогічну доцільність упровадження таксономічного підходу у практику інструментально-виконавської підготовки, ми враховували думку науковців про те, що правильний вибір цільових орієнтирів одна $з$ головних умов успішного становлення системи управління якістю освіти факультету мистецтв і подальшого іiі розвитку. На думку дослідників, цілі управління якістю підготовки вчителів музики є визначальними, вони спрямовують зміст, методи, організаційні форми освітнього процесу i значною мірою 
детермінують успіх педагогічних дій. Такі цілі $\epsilon$ ідеальним, усвідомлено спланованим результатом освітнього процесу, який виражається ву якості знань, умінь і навичок; змінах, що відбуваються в особистісних якостях, характері студентів, їхніх стосунках, ціннісних орієнтаціях [1, с. 142-143].

Із наукової точки зору, ціль - це умовне зображення майбутнього результату, це «вектор» діяльності, який визначає їі напрямок, а також величину зусиль, що розвиває суб'єкт під час її виконання» [1, с. 26]. Алгоритм формулювання цілей був запропонований Дж. Морриссєєм, який визначив його основні положення, зокрема:

- конкретизувати кінцевий результат; конкретизувати строк досягнення цілі;

- конкретизувати максимальну кількість затраченого часу, енергії;

- надавати, де необхідно, якісну характеристику результату робіт, для підтвердження факту досягнення цілі;

- бути зрозумілою тим, хто працюватиме над іï досягненням;

- збігатися 3 інтересами виконавців і не викликати конфліктів під час виконання [2, с. 48].

Аналіз сучасних досліджень (В. Адрущенко, В. Бондар, В. Кремень, М. Поташник та ін.) дозволив визначити ієрархію цілей, що визначають сутність і зміст сучасної системи педагогічної освіти, зокрема це: соціальне замовлення суспільства, Державний освітній стандарт, особистісні потреби студентів, цілі окремих дисциплін, цілі навчальних занять. Вони стимулюють, активізують, організовують діяльність вищих навчальних закладів на розвиток конкурентоспроможної, творчої особистості, яка на основі накопиченого професійного досвіду й узагальнених знань могла б активно впливати на духовноморальний клімат суспільства, відтворювати і зберігати вітчизняні педагогічні й культурні традиції на новому якісному рівні.

Підготовка вчителів музики у вищих педагогічних навчальних закладах суттєво відрізняється від традиційної системи навчання і передбачає проведення занять в індивідуальній формі зі спеціальних предметів (інструмент, диригування, вокал), що актуалізує проблему взаємодії викладача і студента у визначенні проміжних i кінцевих цілей навчання, які б стимулювали, організовували, активізували дії студентів у напрямку досягнення професійного успіху. Ураховуючи, що спонукальна сила цілі полягає в іiі усвідомленості, визначеності, конкретності, співвіднесенні 3 іншими цілями особистості одним із першочергових завдань викладача, зокрема основного музичного інструмента, дослідники (С. Рахімбаєва, С. Протасова та ін.) уважають залучення до процесу цілепокладання студентів, узгодження 3 ними домінуючих i додаткових цілей (відповідно до особистісних потреб) та підпорядковування їх єдиній меті- підготовка компетентного спеціаліста для музично-педагогічної галузі.

Особливу увагу при цьому слід приділяти цілям, зорієнтованим на особистісні потреби студентів. Вони складаються на основі розуміння майбутнього професійного статусу і призначення; оцінки ролі виконавської підготовки в майбутній професійній діяльності, інтересу до предмета, потреби в накопиченні і розширенні компетенцій у виконавській галузі.

Важливим для інструментально-виконавської підготовки майбутніх учителів музики $\epsilon$ формування у студентів умінь цілеутворення, зокрема: прийняття i розуміння цілі, поставленої викладачем, іiї збереження впродовж тривалого часу i підпорядкування їй своєї навчальної діяльності; самостійної постановки цілей

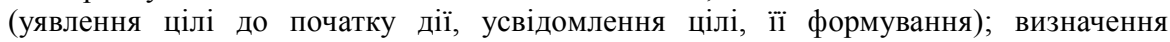


реальності досягнення цілі, її співвіднесення з своїми потенційними можливостями i заміна нереальних цілей реальними; визначення послідовності головних i другорядних цілей з урахуванням рівня досягнення попередніх цілей (результатів виконання навчальних дій); конкретизації цілі, визначення їі залежності від умов і у зв'язку 3 цим постановка нових завдань. При цьому внутрішні і зовнішні цілі повинні співвідноситись між собою, діяти за принципом взаємоузгодженості. Взаємоузгодженість, усвідомленість, визначеність і конкретність навчальних i виховних цілей у процесі інструментально-виконавської підготовки забезпечує якісно новий рівень взаємодії викладачів i студентів, надає їй творчого i перетворювального характеру, спрямовує на досягнення досконалості в музичному виконавстві.

Необхідність концептуалізації питань якості інструментально-виконавської підготовки вчителя музики посилюється соціальним замовленням на відповідні інформаційному суспільству цілі, завдання, форми, якість вищої освіти, і передовсім на особистість фахівця, здатного до швидкої, гнучкої зміни своєї життєдіяльності. Це створює об'єктивні умови для перегляду теоретико-методичних основ інструментального навчання у вищій школі, що склалися за останнє сторіччя. Подолання репродуктивного стилю підготовки вчителів музики i перехід до дидактичної парадигми, котра забезпечить пізнавальну активність і професійну креативність студентів $\epsilon$, на наш погляд, одним із стратегічних напрямів підвищення якості навчання гри на музичних інструментах майбутніх викладачів музичного мистецтва. При цьому розуміння якості інструментально-виконавської підготовки істотно трансформується. Вона визначається не тільки мірою засвоєння випускником педагогічного ВНЗ виконавських знань, умінь і навичок, а й тим, наскільки майбутній учитель може застосувати їх на практиці.

Упровадження таксономічного підходу в практику інструментальновиконавської підготовки передбачає цільову орієнтацію процесу навчання на кінцевий результат, що зумовлює пошук раціонально обгрунтованих оптимальних варіантів навчально-пізнавальних i креативно-виконавських дій викладача i студента; взаємовплив традиційних i новітніх методик навчання, взаємодію педагогічних практик та діалогову стратегію спілкування. Цей підхід дає можливість об'єднати необхідні знання, уміння, навички з різних мистецьких дисциплін, виконавської діяльності в єдину систему задля підвищення якості виконавської підготовки фахівців мистецької галузі та формування особистості майбутнього вчителя музики, цільові орієнтири якого спрямовані на досягнення навчального і професійного успіху.

Проблема підвищення якості інструментально-виконавської підготовки в педагогічних ВНЗ актуалізується ще й у зв'язку зі збагаченням змісту відповідних дисциплін, а також усвідомленням того, що виконавське мистецтво володіє невичерпним педагогічним i творчим потенціалом i $\epsilon$ найважливішим засобом навчання, виховання і розвитку особистості вчителя музики впродовж життя. Інструментально-виконавська підготовка у вищих навчальних закладах освіти має бути: об'єктивною (відображати суттєве); суб'єктивною (відображати суб'єкт 3 урахуванням його потенційних можливостей); нормативною (відображати ідеї науково-мистецької парадигми освіти); адаптивною (пристосовуватись до запитів музично-педагогічної діяльності й інтересів студентів); інтерактивною (передбачати діалог між суб'єктами та об'єктами навчально-виконавської діяльності); відкритою (передбачати оновлення та модернізацію). 
Здійснюючи дослідження, ми виходили 3 припущення, що рушійною силою процесу інструментально-виконавської підготовки майбутніх учителів музики постає суперечність між вимогами суспільства до якості підготовки фахівців мистецької галузі та низькою конкурентоспроможністю значної частини випускників вищих навчальних закладів на ринку праці.

Механізмом функціонування визначаємо ієрархічну систему педагогічних цілей, спрямованих на стимулювання внутрішньої готовності студентів до навчального та професійного успіху за рахунок поступового їх залучення до творчої, аксіологічно та акмеологічно зорієнтованої виконавської діяльності.

Мета інструментально-виконавської підготовки полягає у спрямуванні процесу навчання на досягнення високого рівня готовності студентів до виконавської діяльності на основі посилення їх світоглядної, мотиваційно-ціннісної та операційної позиції в навчально-виконавській діяльності.

Реалізація мети передбачає розв'язання таких завдань:

- створення i впровадження моделі інструментально-виконавської підготовки, що дозволить інформувати, адаптувати, орієнтувати та розвивати студентів у напрямку навчального і професійного успіху;

- усунення змістової роздрібненості дисциплін виконавського профілю (основний музінструмент, концертмейстерський клас, виконавська практика, методика викладання музичного інструмента, спецкурси);

- зорієнтованість на високий рівень виконавської підготовленості студентів під час проектування змісту інструментальної підготовки майбутнього вчителя музики;

- організація нової якості взаємодії «студент-викладач» на основі взаємоузгодженості, усвідомленості, визначеності і конкретності навчальних і виховних цілей;

- консолідація зусиль викладачів на розвитку успішної особистості майбутніх учителів музики шляхом забезпечення поетапного формування у студентів інтелектуальних, вольових, емоційних, характерологічних та професійних якостей;

- упровадження у практику інструментально-виконавської підготовки майбутніх учителів музики тембрового підходу;

- спрямування процесу навчання на реалізацію не лише вузько- предметних цілей, а й на досягнення «надпредметних»- широких розвивальних, виховних, культуротворчих завдань фахової підготовки вчителів музики;

- розроблення системи оцінювання та контролю процесу навчання гри на музичних інструментах та відповідних видів діяльності;

- підвищення практичної спрямованості інструментально-виконавської підготовки майбутніх учителів музики.

Орієнтація на таксономічний підхід як провідний методологічний орієнтир дослідження передбачає реалізацію таких ідей:

- циклічності й логічної завершеності реалізації поставлених педагогічних цілей на всіх етапах інструментально-виконавської підготовки вчителя музики;

- поважного ставлення до суб'єктів навчання, визначення їх активними учасниками освітнього процесу, управління яким повинно здійснюватись відповідно до принципів рівності та здібностей; 
- формування успішної особистості вчителя музики на засадах гуманізму, співробітництва і співтворчості, що стимулює сумісний пошук, віру в студента i його право на власну позицію;

- збереження освітніх традицій і пошук механізмів їхньої трансформації в новому соціально-технологічному середовищі.

На наш погляд, актуалізація вищезазначених ідей дозволяє обгрунтувати принципові положення функціонування й розвитку системи інструментального навчання майбутніх учителів музики, обгрунтувати основні позиції необхідних змін та визначити очікувані результати, максимально сконцентрувати необхідні ресурси (матеріально-технічні, фахово-професійні) задля розв'язання наявних проблем i досягнення оптимального результату.

Своєрідним регулятором якості інструментально-виконавської підготовки майбутніх учителів музики у дослідженні визначено загальнонаукові (єдності теорії і практики, гуманізації, науковості, системності, інформативності, проблемності, інтегративності, прогностичності, варіативності) і розроблені й обгрунтовані нами дисциплінарні (виконавські) принципи, а саме: урахування педагогічної спрямованості виконавської підготовки вчителів музики, образно-змістового осмислення виконавських дій, тембральної спрямованості виконавського навчання, забезпечення стильової палітри виконавського репертуару, інтеграції різних напрямків виконавської підготовки, цілеспрямованої творчої взаємодії викладача і студента в досягненні виконавського успіху.

Реалізація означених принципів вимагає запровадження у структуру і зміст виконавського навчання змін, зорієнтованих на сучасні вимоги до фахівців у галузі мистецької освіти $з$ урахуванням європейських стандартів. Для цього необхідно перетворити процес навчання гри на музичних інструментах на організаційнометодичну систему інструментально-виконавської підготовки майбутніх учителів музики, розроблення якої необхідно здійснювати з урахуванням таких позицій:

- визначення філософської, загальнонаукової та музикознавчої основи дослідження інструментально-виконавської підготовки вчителів музики;

- обгрунтування мети, завдань, структури, основних видів діяльності, змісту і форм організації процесу навчання гри на музичних інструментах;

- організація науково-методичної та дослідно-пошукової роботи.

Принциповим у дослідженні стало положення, згідно з яким інструментальновиконавська підготовка повинна мати особистісне, практичне спрямування на формування готовності студентів до інструментально-виконавської діяльності, розкриття їхніх потенційних можливостей, інтелектуального й емоційно-вольового розвитку, здатності до самореалізації та рефлексії власної діяльності.

\section{Література}

1. Рахимбаева И. Э. Теоретические основы управления качеством высшего педагогического художественно-творческого образования на факультете искусств: монография / И. Э. Рахимбаева. - С. : Наука, 2008. - 215 с. 2. Мориссей Дж. Целевое управление организацией / Дж. Мориссей. - М. : Советское радио, 1979. $144 \mathrm{c}$. 